\title{
The shallow structure beneath Montserrat (West Indies) from new Bouguer gravity data
}

\author{
Stefanie Hautmann, ${ }^{1}$ Antonio G. Camacho, ${ }^{2}$ Joachim Gottsmann, ${ }^{1}$ Henry M. Odbert, ${ }^{1,3}$ \\ and R. Tappy Syers ${ }^{3}$
}

Received 13 August 2013; revised 27 September 2013; accepted 27 September 2013; published 9 October 2013.

[1] Although the persistently active Soufrière Hills Volcano (Montserrat, West Indies) is one of the most extensively studied active stratovolcanoes, a local Bouguer gravity map of the volcano and the island of Montserrat has yet to be constructed. We collected 157 new gravity data, which we analyzed and inverted in order to constrain the island's subsurface density distribution. Our model results reveal high-density material beneath the centers of the extinct volcanic complexes - presumably related to exposed dome cores - while the volcanic flanks and the active Soufrière Hills Volcano are underlain by low-density material. Volcaniclastic deposits and subsurface melt aggregations, respectively, may explain these negative gravity anomalies. Our results are in good agreement with previous structural observations from seismic tomography; however, a higher spatial density of the gravity survey network has allowed us to additionally capture smaller, shallow-seated anomalies in the gravity field that relate to tectonic structures and fluvial filling deposits. Citation: Hautmann, S., A. G. Camacho, J. Gottsmann, H. M. Odbert, and R. T. Syers (2013), The shallow structure beneath Montserrat (West Indies) from new Bouguer gravity data, Geophys. Res. Lett., 40, 5113-5118, doi:10.1002/grl.51003.

\section{Introduction}

[2] Static gravity data can be used to identify spatial heterogeneities in the Earth's gravity field by providing information on the density distribution in the shallow subsurface. As such, the collection, reduction, and analysis of static gravity data contribute to the understanding of the subsurface architecture, geology, and tectonic evolution of an investigated survey area. Knowledge of the subsurface density distribution and identification of structural discontinuities are of particular interest in active volcanic regions [e.g., Fournier et al., 2004; Zurek and Williams-Jones, 2013; del Potro et al., 2013], as they can have implications for fluid migration [Sibson, 1994], edifice stability [Reid et al., 2000], the subsurface transfer of volcanically induced

Additional supporting information may be found in the online version of this article.

${ }^{1}$ School of Earth Sciences, University of Bristol, Bristol, UK.

${ }^{2}$ Instituto de Astronomìa y Geodesia (CSIC-UCM), Facultad de Ciencias Matemàticas, Universidad Complutense Madrid, Madrid, Spain.

${ }^{3}$ Montserrat Volcano Observatory, Flemmings, Montserrat, British West Indies.

Corresponding author: S. Hautmann, School of Earth Sciences, University of Bristol, Wills Memorial Bldg., Queens Rd., Bristol BS8 1RJ, UK. (stefanie. hautmann@googlemail.com)

(C)2013. American Geophysical Union. All Rights Reserved. 0094-8276/13/10.1002/grl.51003 stresses, and, consequently, the interpretation of recorded geodetic data [e.g., Folch and Gottsmann, 2006; Geyer and Gottsmann, 2010].

[3] The island of Montserrat (West Indies) hosts the andesitic dome-building Soufrière Hills Volcano (SHV), which reactivated in 1995 and has since undergone phases of dome growth and destruction interspersed by periods of very low eruptive activity. Although SHV is currently one of the most extensively studied actively erupting stratovolcanoes, a local Bouguer anomaly map of the volcano and the island of Montserrat had been absent. We therefore conducted a Bouguer gravity survey on Montserrat in order to document spatial variations in the island's gravity field to shed light on subsurface density distribution and structural discontinuities. Our survey was particularly aimed at detecting smallscale anomalies at shallow depths that are hitherto not resolved in tomographic studies from Montserrat [e.g., Shalev et al., 2010] but which potentially affect subsurface dynamic processes and its associated geophysical signals.

\section{Data Collection and Reduction}

[4] A total of 157 new gravity measurements was collected on Montserrat between April 2011 and July 2012 using a Scintrex CG-5 gravity meter (ID 40663). The Bouguer gravity network provides a dense coverage (distance of around $200 \mathrm{~m}$ between neighbouring sites) of the accessible regions of older volcanic complexes: Silver Hills (SH) and Centre Hills (CH), both located north of the active SHV (Figure 1a). The Belham River Valley and Soldier Ghaut, which have been described as surface expressions of active faults/fault zones [Feuillet et al., 2010; Hautmann et al., 2010a], were covered by a denser observation network (distance between adjacent measurement sites approximately $100 \mathrm{~m}$ ). Attempts to survey the central $\mathrm{CH}$ were generally unsuccessful due to a combination of two effects: (i) the dense vegetation limits the use of GNSS (Global Navigation Satellite System) for precision positioning; and (ii) the soft soils on the steep slopes of the $\mathrm{CH}$ do not provide adequate ground stability for precise gravity measurements. We undertook several expeditions to survey about a dozen sites located in the inner complex of the $\mathrm{CH}$, which proved to be suitable for high-precision gravity measurements. Rather than having additional, poor-quality measurements, we focused instead on collecting high-precision data mainly in the accessible parts of the island. Due to the limited accessibility of southern Montserrat because of threats posed by volcanic hazards, the network coverage around SHV is more sparse, with about $1 \mathrm{~km}$ distance between neighboring sites.

[5] Gravity data were referenced to a base located between the $\mathrm{SH}$ and the $\mathrm{CH}[585,469.24 \mathrm{~m}, 1,856,915.88 \mathrm{~m}, \mathrm{WGS} 84$ 


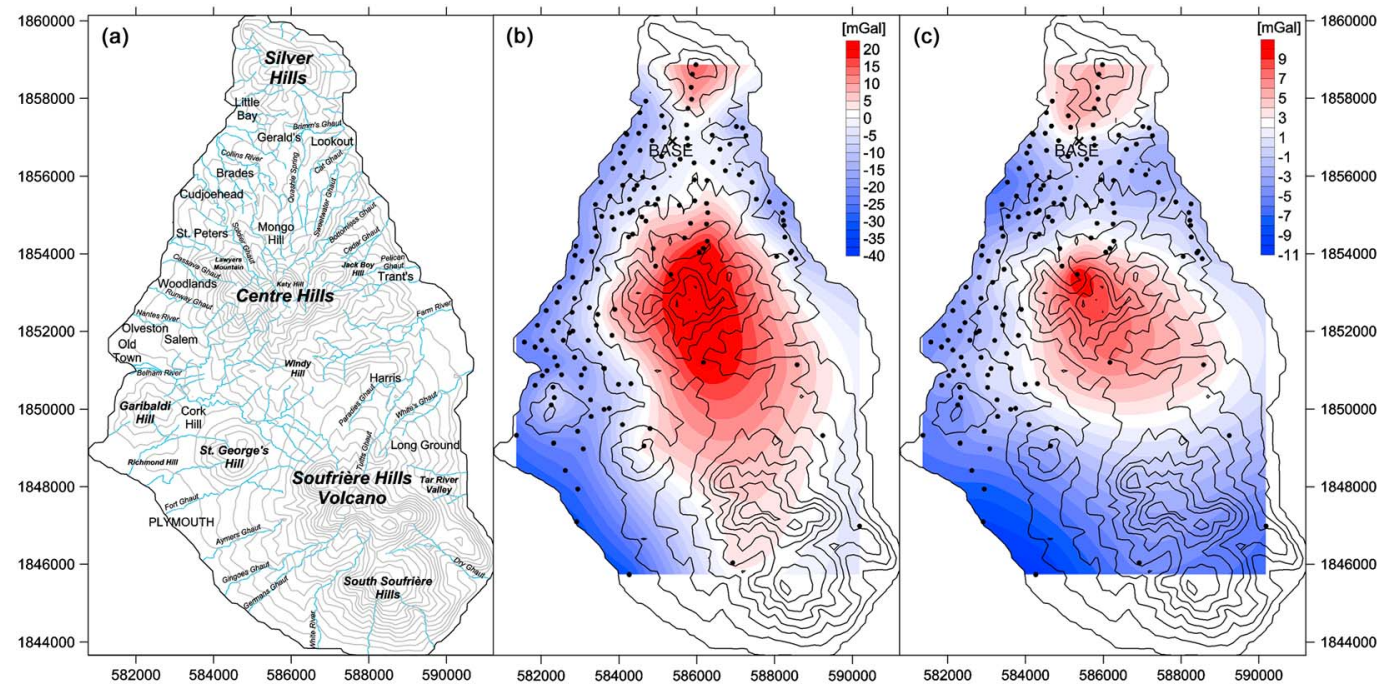

Figure 1. (a) Topographic, (b) free-air gravity anomaly, and (c) Bouguer anomaly maps of Montserrat. Gravity sampling sites are shown by black points in Figures $1 \mathrm{~b}$ and $1 \mathrm{c}$. High-density anomalies are shown in red, while low-density anomalies are shown in blue. Gravity values are relative to a base site, which is located near Gerald's in the north of Montserrat and marked with a black cross. Data interpolation in the low network density areas (inner Centre Hills, active Soufrière Hills Volcano) is illustrative only and may not be accurate.

UTM Zone 20Q; elevation $167.88 \mathrm{~m}$ above sea level (asl)]. The location of the reference site was chosen based on its accessibility and distance from the volcano in order to avoid potential disturbances due to volcanic activity. The reference was occupied about 4 times $\mathrm{d}^{-1}$ in order to correct data for instrument drift and tares. The accuracy of the individual readings is within $\pm 0.01 \mathrm{mGal}$. Site positions and elevations were determined via a TOPCON Hiperpro dual-frequency GNSS receiver/antenna operating at $0.5 \mathrm{~Hz}$ for about $10 \mathrm{~min}$ at each site. Postprocessing of the GNSS data was performed using the permanent local GPS network as a reference [Mattioli et al., 2010]. Using the software Leica GeoOffice, we obtained vertical accuracy of about $3 \mathrm{~cm}$ for most of the sites.

[6] The recorded gravity data were corrected for solid Earth tides and ocean loading using a tidal model for Montserrat (MTY11) [Hautmann et al., 2013]. Standard techniques were applied in order to mitigate the influence of benchmark elevation (free-air effect; Figure 1b) and latitude [Moritz, 1980; Walsh, 1975]. The correction for topographic effects (onshore Montserrat and offshore regions) on gravity measurements was performed via an automated algorithm that uses 34 circular zones split into 894 compartments (similar to Hammer zones) [Hammer, 1939] around each individual measurement site. A digital elevation model (DEM) with grid postings at $10 \mathrm{~m}$ together with an offshore bathymetric model with $250 \mathrm{~m}$ postings [Montserrat Volcano Observatory, 2010] were applied to calculate the average elevation of the individual compartments and correct gravity measurements for terrain effects. The DEM was constructed from preeruption aerial photograms and stereo photogrammetry DEM patches updated by Wadge [2000]. The DEM was digitized at $25 \mathrm{~m}$ postings and resampled at $10 \mathrm{~m}$ postings via a Kriging algorithm. The differences between GNSS-surveyed heights and corresponding DEM heights at collection sites vary between $0.1 \mathrm{~m}$ and $16 \mathrm{~m}$. This uncertainty translates as a $0.1 \mathrm{mGal}$ error in the terrain correction [Kloch and Kryński, 2008]. To account also for the roughness of terrain on Montserrat, which further limits the accuracy of gravity terrain corrections [Kloch and Kryński, 2008], we assume an uncertainty of $0.3 \mathrm{mGal}$ in our terrain-corrected gravity data.

[7] The comparison of gravity and elevation data permits an assessment of the terrain density. In fact, according to a general assumption from Nettleton [1939], a suitable terrain density value must give a minimum correlation between gravity anomaly $\Delta g$ and elevation $h$. However, this approach can yield erroneous density estimates. For example, on young volcanic islands, gravity and topography can be correlated due to deep structural features, such as shield structures. In such cases, a more realistic value for the terrain density can be obtained by seeking the minimum correlation between short-wavelength components of both gravity and topography [Gottsmann et al., 2008]. Long-wavelength components can be filtered by subtracting the average gravity values and elevation of benchmarks within circular areas at preassigned radii, $r$, around each collection site. Figure 2 gives the derived terrain densities as a function of $r$. The results show a chaotic pattern for $r<0.5 \mathrm{~km}$, a mean value of $2300 \mathrm{~kg} / \mathrm{m}^{3}$ for $r$ between $0.5 \mathrm{~km}$ and $1.3 \mathrm{~km}$, and an increasing terrain density for averaging $r>1.3 \mathrm{~km}$. The latter reflects the correlation between large, high-density structures and relief at longer spatial scales. Based on these results, we choose a terrain density of $2300 \mathrm{~kg} / \mathrm{m}^{3}$ for the correction of our gravity data but additionally account for the oceanic (water) mass with a density of $1060 \mathrm{~kg} / \mathrm{m}^{3}$.

[8] The reduced gravity data were then applied for the construction of the Bouguer anomaly map, as shown in Figure 1c, which documents the subsurface density distribution beneath the survey area.

\section{Modeling}

[9] In order to model the Bouguer gravity data, we performed a nonlinear inversion using the software package GROWTH 2.0 [Camacho et al., 2011]. The inversion is based on a 3-D aggregation of quadratic cells that are filled, 


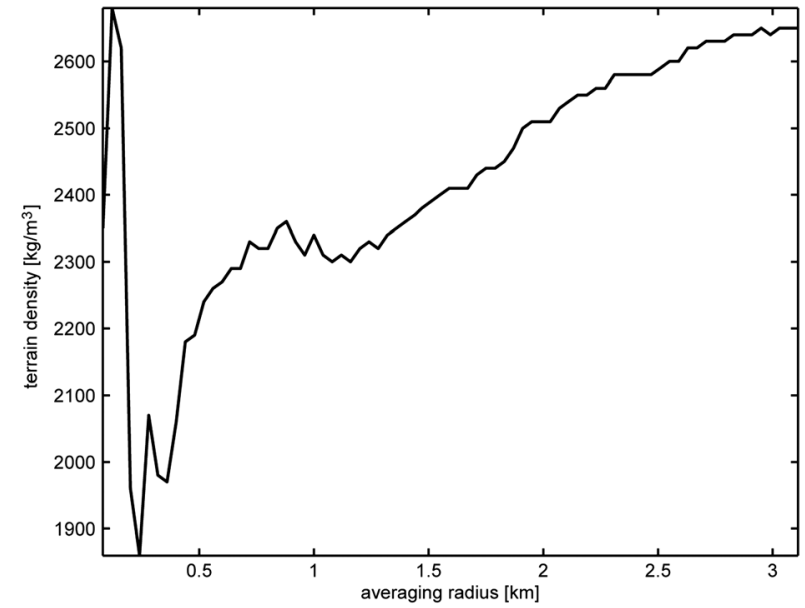

Figure 2. The optimum terrain density is obtained for the minimum correlation between short-wavelength components of gravity and site elevations within circular areas at preassigned radii around each benchmark. The graph shows (specifically for Montserrat) the inferred terrain densities as a function of the wavelength of the investigated circular areas. A mean value of $2300 \mathrm{~kg} / \mathrm{m}^{3}$ is obtained for circular areas with radii between 0.5 and $1.3 \mathrm{~km}$. High-density values for longer wavelength components $(>1.3 \mathrm{~km})$ result from the correlation between high-density structures and topography.

via a growth process, by means of prescribed positive and/or negative density contrasts. This automated methodology provides an unconstrained 3-D geometry of the anomalous bodies, minimizing misfit with the observed Bouguer anomaly [Camacho et al., 2011]. In our model configuration, we partitioned the subsurface volume of Montserrat into 67,000 quadratic cells with sides of $150 \mathrm{~m}$ in length.

[10] Preassumptions on the density contrasts of the Bouguer anomalies are among the most critical parameters for gravity inversion. Results from 3-D seismic tomography studies on Montserrat suggest rock density differences of $200 \mathrm{~kg} / \mathrm{m}^{3}$ and $500 \mathrm{~kg} / \mathrm{m}^{3}$ between older volcanic dome complexes and volcaniclastic deposits: Shalev et al. [2010] estimated $2200 \mathrm{~kg} / \mathrm{m}^{3}$ for talus apron material and $2400 \mathrm{~kg} /$ $\mathrm{m}^{3}$ for dome rock, while Paulatto et al. [2010] estimated $2100 \mathrm{~kg} / \mathrm{m}^{3}$ for talus and $2600 \mathrm{~kg} / \mathrm{m}^{3}$ for dome rock. When running our model with the density contrasts derived from the seismic studies, we find that small density contrasts give a good resolution of structures at shallow crustal depths but cannot reproduce the large Bouguer anomalies. In turn, accounting for higher density contrasts enables us to reproduce the large anomalies but does not allow us to satisfactorily resolve shallow-seated structures. We therefore assume in our modeling a density contrast of $\pm 180 \mathrm{~kg} / \mathrm{m}^{3}$ for shallow crustal structures but account for the large observed anomalies by allowing for deep-rooted structures with larger density contrasts of $\pm 340 \mathrm{~kg} / \mathrm{m}^{3}$. The resulting best fit of model to data has a standard deviation of $0.26 \mathrm{mGal}$.

[11] With network spacing between 100 and $200 \mathrm{~m}$ in the accessible regions of Montserrat, the wavelength of gravity anomalies that we can theoretically resolve in these data must be larger than $200 \mathrm{~m}$ (i.e., the Nyquist wavelength for sample intervals of $100 \mathrm{~m}$ ). Since the average elevation of the gravity network is $150 \mathrm{~m}$ asl, we are therefore able to detect anomalies at depths in excess of $50 \mathrm{~m}$ below sea level (bsl). To test the sensitivity of the inversion routine for the particular gravity network established on Montserrat, we ran a number of resolution tests. The resolution tests are based on the checkerboard approach - a routine sensitivity test usually applied in seismic studies [Shearer, 2009]. We simulate a simplified, anomalous structure of negative and positive density contrasts and calculated (via forward modeling with GROWTH 2.0) the corresponding gravity signals for each of the benchmarks visited during the survey. The inferred gravity data were then inverted in order to constrain the depth to which inversion adequately represents the simulated structure. Note that gravity data are much more sensitive to lateral discontinuities than they are to horizontal stratification. We account for this by running the simulations with an anomalous structure that consists of vertical columns that represent a "chess" pattern in the top map view with lateral side lengths of $3 \mathrm{~km}$, $1.5 \mathrm{~km}$, and $0.7 \mathrm{~km}$. Results show that the GROWTH 2.0 inversion of data from the gravity network gives a good resolution of large-scale subsurface structures to depths between 3 and $4 \mathrm{~km}$ bsl, while small-scale structures are well reproduced to depths between 0.5 and $0.8 \mathrm{~km}$ bsl in areas of dense network coverage. The results are given in Figure S1 in the supporting information.

\section{Results and Discussion}

[12] The local Bouguer anomaly map of Montserrat reveals a spatially coherent pattern with gravity varying over a 22 mGal range (Figure 1). Our results show high-density bodies beneath the centers of the extinct volcanic complexes Silver Hills ( $\mathrm{SH})$ and Centre Hills $(\mathrm{CH})$. In contrast, the active Soufrière Hills Volcano (SHV) and the flanks of the SH and the $\mathrm{CH}$ are low-density zones. Horizontal sections at different depths show the deep roots of the modeled anomalous, high-density bodies beneath the $\mathrm{CH}$ and the $\mathrm{SH}$ to about $5000 \mathrm{~m}$ bsl (Figure 3), while the low-density aprons appear to reach depths of down to $1000 \mathrm{~m}$ bsl and are inclined toward the sea at angles between $30^{\circ}$ and $45^{\circ}$ (Figure 4 ), which is about the angle of a natural rubble-talus slope [Carson, 1977]. The accuracy of inferred dimensions for large-scale anomalies is restricted by the domain sensitivity of the model, which, in turn, is limited by the size of the island and of the survey area. To fully constrain the dimensions of large-scale structures beneath Montserrat, our results and processing would require information from additional offshore gravity data.

[13] High-density regions are likely to correspond to subsurface extension of the exposed dome rocks of the $\mathrm{CH}$ and the $\mathrm{SH}$, while the surrounding low-density regions are best explained by aprons of volcaniclastic debris surrounding the extinct domes. Our results allow us to estimate the volumes of the intrusive complexes as $75 \mathrm{~km}^{3}$ for the $\mathrm{CH}$ and $20 \mathrm{~km}^{3}$ for the $\mathrm{SH}$, respectively (for densities $>2300 \mathrm{~kg} / \mathrm{m}^{3}$ to $5 \mathrm{~km} \mathrm{bsl}$ ). Given that we are not able to image the full extent of the complexes, which would be about 3 times larger for a magmatic system extending to $15 \mathrm{~km}$ bsl [Hautmann et al., 2010b], we find that the core complexes beneath Montserrat's volcanoes are about an order of magnitude smaller than those of Hawaiian shield volcanoes [Flinders et al., 2013]. The low-density anomaly around SHV may be influenced by either the melt accumulation in the subsurface and/or the presence of low-density and potentially hydrothermally altered rocks. However, the sparsity of benchmarks 


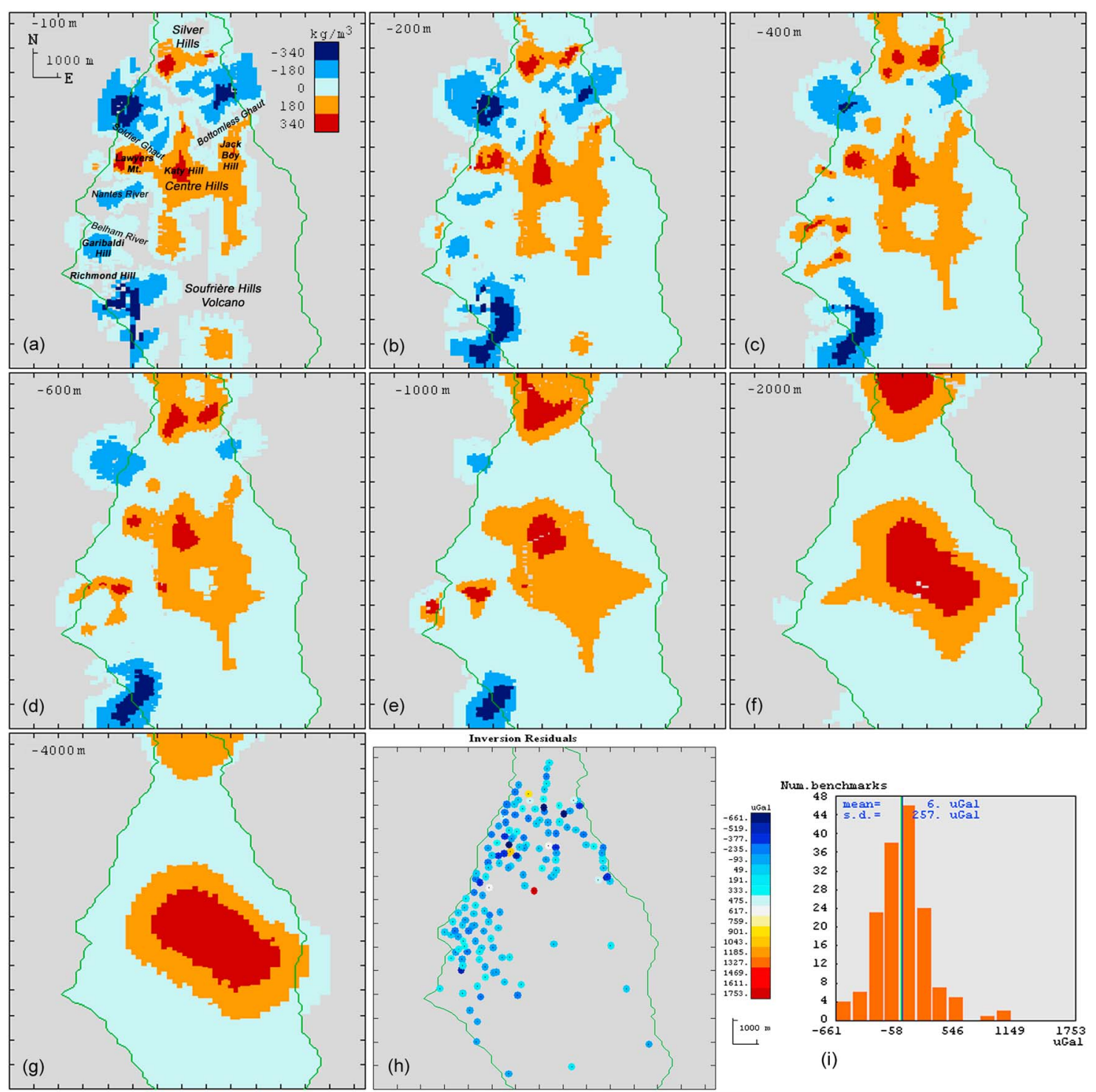

Figure 3. Inversion results of the reduced gravity data showing modeled anomalies in horizontal sections at depths of (a) $100 \mathrm{~m}$, (b) $200 \mathrm{~m}$, (c) $400 \mathrm{~m}$, (d) $600 \mathrm{~m}$, (e) $1000 \mathrm{~m}$, (f) $2000 \mathrm{~m}$, and (g) $4000 \mathrm{~m}$ bsl. Locations of key topographic features, which are discussed in the text, are indicated in Figure 3a. Best fit results were found for a density contrast of -340 to $340 \mathrm{~kg} / \mathrm{m}^{3}$. (h, i) Inversion residuals and inversion statistics. The one standard deviation of the presented model solution is $0.26 \mathrm{mGal}$.

around SHV precludes a detailed analysis of the gravity field in the immediate vicinity of the active volcano; interpretations should be regarded as first-order approximations. The overall results shown in our Bouguer map (Figure 1) agree well with observations from seismic tomography that were obtained from the SEA-CALIPSO (Seismic Experiment With Airgun Source-Caribbean Andesitic Lava Island Precision Seismo-Geodetic Observatory) experiment conducted in 2007 [Paulatto et al., 2010; Shalev et al., 2010]. Checkerboard tests showed that the seismic data reliability indicates anomalies with $1.5 \mathrm{~km}$ wavelength at minimum located at depths between 1 and $4 \mathrm{~km}$. For depths $<1 \mathrm{~km}$, the resolution significantly decreases [Shalev et al., 2010]. Owing to a higher spatial density in our gravity survey compared to that of the seismic study, 3-D inversion of the gravity data enables us to resolve anomalies caused by significantly smaller-scale structures at shallow depths.
[14] Results from gravity inversion show that the modeled density anomalies correspond well to topographic features and lithological changes that are exposed at the surface. In particular, the high-density anomalies in the shallow subsurface of the $\mathrm{CH}$ correlate with the surface remnants of old volcanic domes (Lawyers Mountain, Katy Hill, including the ridge of Mongo Hill, Jack Boy Hill; Figure 3). The modeled contact between the high-density anomaly that is associated with the volcanic complex SH in the north of Montserrat and the low-density volcaniclastic deposits of the $\mathrm{CH}$ is identical to the exposed boundary between these units at the surface [cf. Harford et al., 2002]. Negative Bouguer anomalies on the flanks of the $\mathrm{CH}$ coincide with some major valleys (Nantes River in the west, Soldier Ghaut and Collins River in the northwest, and Cat Ghaut and Sweetwater Ghaut in the northeast) and represent the low-density fluvial infill of the eroded valleys ("ghauts"). 


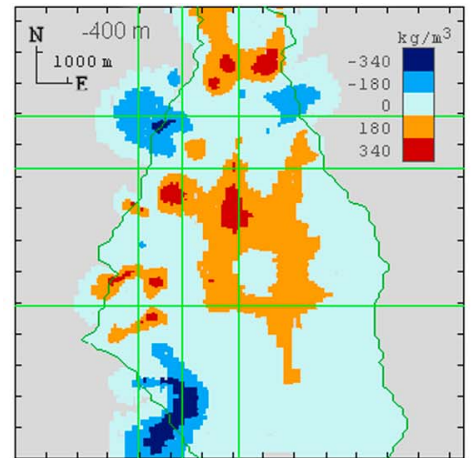

(a) (b) (c)

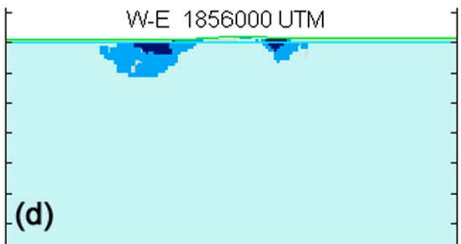

(d)
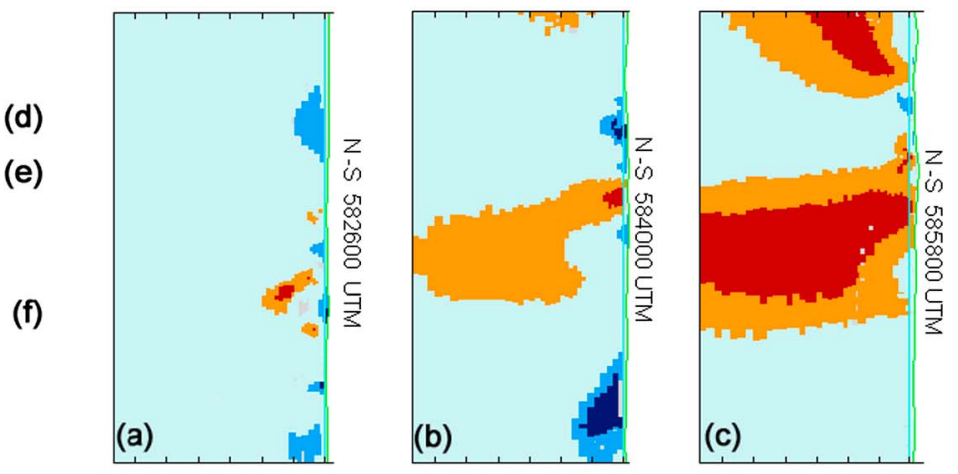

(c)

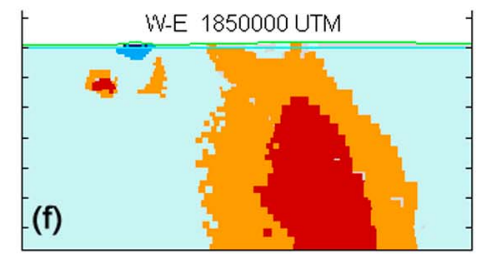

Figure 4. Inversion results of the reduced gravity data showing modeled anomalies in $(\mathrm{a}-\mathrm{c})$ vertical N-S profiles and $(\mathrm{d}-\mathrm{f})$ W-E profiles. The trail lines of the profiles are indicated in the horizontal section.

[15] The most prominent feature of the modeled smallscale anomalous structures in the shallow subsurface (i.e., $<600 \mathrm{~m}$ bsl) is a low-density body beneath Garibaldi Hill (Figures 1,3, and 4), located in the west of Montserrat, south of Belham River Valley. Our inversion models this body to a depth of $300 \mathrm{~m} \mathrm{bsl}$, bound to the north and to the south by high-density bodies that penetrate to between 300 and $800 \mathrm{~m}$ bsl. Garibaldi Hill and St. Georges Hill are both thought to be horst structures, comprising uplifted volcaniclastic deposits [Harford et al., 2002]. We propose that the low-density anomaly of Garibaldi Hill represents uplifted volcaniclastic deposits, while the high-density structures might relate to the bounding (recently inactive) faults of the raised block. Geothermal fluid circulation in the region beneath Richmond Hill-Garibaldi-St. Georges [Chiodini et al., 1996; Rowe et al., 2004; Kenedi et al., 2010; Ryan et al., 2013] might have resulted in increased hydrothermal mineralization in the fault damage zone that has resulted in higher density and, thus, a positive gravity signal. Note that hydrothermal silicification, other than alteration, produces a higher-density rock [Zimbelman et al., 2004]. Alternatively, the fault zone may have provided a pathway for magma intrusion, and the high-density anomaly represents solidified dike structures. Due to the elevated volcanic risk for surveying around St. Georges Hill, our measurement density is less compared to Garibaldi Hill. As a consequence, we cannot test for a common structural origin of both Garibaldi Hill and St. Georges Hill, as proposed by Harford et al. [2002].

[16] The deepest valleys on Montserrat - Soldier Ghaut and Bottomless Ghaut (NW and NE of the $\mathrm{CH}$ ) - abut upon the high-density andesitic lava massifs of Lawyers Mountain and Jack Boy Hill. Earlier studies [Chiodini et al., 1996; Hautmann et al., 2010a] suggested that the valleys are aligned with fault planes. However, based on the available Bouguer data, we cannot constrain whether Soldier Ghaut and Bottomless Ghaut result from a fault-related crustal weakness, which might have also facilitated the formation of Lawyers Mountain and Jack Boy Hill as it provided a pathway for magma to break through the surface. Alternatively, the valleys could have been also formed by enhanced erosion along the structural discontinuity that results from the sharp contact between the high-density andesitic lava bodies and the lowdensity flank deposits.

[17] Surprisingly, our data fail to reveal any near-surface structures associated with the active Belham Valley fault [e. g., Chiodini et al., 1996; Feuillet et al., 2010; Kenedi et al., 2010]. We did not detect a near-surface horizontal gradient in gravity across the fault that would correlate with a change in lithology due to a subvertical offset of the faults. Nor did we find a local low-gravity anomaly which would be expected to coincide with a decrease in density due to fractured rocks in an active fault damage zone. In comparison, results from new magnetotelluric and time-domain electromagnetic induction measurements revealed a low-resistivity anomaly at shallow depths beneath the Belham valley [Ryan et al., 2013] (G. A. Ryan et al., Imaging the Montserrat geothermal prospect using magnetotelluric (MT) and time domain electromagnetic induction (TDEM) measurements, unpublished report 16366.00-2009.01, Auckland Institute of Earth Sciences and Engineering, 2009), which has been explained as the result of fault-related fractures hosting geothermal fluids. We are unable to support or reject this hypothesis based on our Bouguer gravity data. The Belham Valley might be disrupted by a number of smaller-scale faults that would be only resolved when surveying along a denser network of benchmarks. However, it might be equally possible that the density difference between the unconsolidated sedimentary infill and the fracture zones is too small to be seen in gravity data.

\section{Conclusions and Outlook}

[18] We have presented results from a new static gravity survey on Montserrat using 157 new gravimetric measurements. The 3-D inversion of the local Bouguer anomaly data enabled an assessment of the island's shallow subsurface architecture. Large and deep-rooted high-density bodies interpreted as magmatic intrusions and remnants of feeder systems form the cores of the extinct volcanic centers 
(Silver Hills and Centre Hills). The surrounding low-density regions represent volcaniclastic aprons around the flanks of the extinct centers. A high-density core of the active Soufrière Hills Volcano was not imaged. Rather, the gravity field around SHV appears to be influenced by comparably low-density structures potentially associated with magma accumulation or the presence of low-density and potentially hydrothermally altered rocks. Small-scale structures modeled by the inversion are interpreted to relate to a low-density, tectonically uplifted body forming Garibaldi Hill and its bounding faults as well as fluvial infill of erosional valleys (e.g., Nantes Ghaut).

[19] Acknowledgments. This research received funding from the Geological Society of London and the German National Academy of Sciences (LPDS 2009-47) (S.H.), the European Research Council Advanced Grant VOLDIES (grant agreement 228064) (H.M.O.), the Royal Society, the Natural Environmental Research Council, and the European Commission under the European Union's Seventh Framework Program (VUELCO; grant agreement 282759) (J.G.). We thank Eric Tomme and the Montserrat Volcano Observatory, namely, Paul Cole and Adam Stinton, for logistical support. Particular thanks to Rodrigo del Potro for sharing his expertise in data inversion using GROWTH 2.0. The authors thank Glyn Williams-Jones and Nicolas Fournier for their helpful reviews.

[20] The Editor thanks Glyn Williams-Jones and Nicolas Fournier for their assistance in evaluating this paper.

\section{References}

Camacho, A. G., P. J., Gonzalez, J. Fernández, and G. Berrino (2011), Simultaneous inversion of surface deformation and gravity changes by means of extended bodies with a free geometry: Application to deforming calderas, J. Geophys. Res., 116, B10401, doi:10.1029/2010JB008165.

Carson, M. A. (1977), Angles of repose, angles of shearing resistance and angles of talus slopes, Earth Surf. Processes Landforms, 2(4), 363-380.

Chiodini, G., R. Cioni, A. Frullani, M. Guidi, L. Marini, F. Prati, and B. Raco (1996), Fluid geochemistry of Montserrat Island, West Indies, Bull. Volcanol., 58, 380-392.

del Potro, R., M. Díez, J. Blundy, A. G. Camacho, and J. Gottsmann (2013), Diapiric ascent of silicic magma beneath the Bolivian Altiplano, Geophys. Res. Lett., 40, 2044-2048, doi:10.1002/grl.50493.

Feuillet, N., et al. (2010), Active faulting induced by slip partitioning in Montserrat and link with volcanic activity: New insights from the 2009 GWADASEIS marine cruise data, Geophys. Res. Lett., 37, L00E15, doi:10.1029/2010GL042556.

Flinders, A. F., G. Ito, M. O. Garcia, J. M. Sinton, J. Kauahikaua, and B. Taylor (2013), Intrusive dike complexes, cumulate cores, and the extrusive growth of Hawaiian volcanoes, Geophys. Res. Lett., 40, 3367-3373, doi: $10.1002 /$ grl.50633.

Folch, A., and J. Gottsmann (2006), Faults and ground uplift at active calderas, in Mechanisms of Activity and Unrest at Large Calderas, Geol. Soc. Spec. Publ, vol. 269, edited by C. Troise, G. De Natale, and C. R. J. Kilburn, pp. 109-120.

Fournier, N., H. Rymer, G. Williams-Jones, and J. Brenes (2004), Highresolution gravity survey: Investigation of subsurface structures at Poa's volcano, Costa Rica, Geophys. Res. Lett., 31, L15602, doi:10.1029/ 2004GL020563.

Geyer, A., and J. Gottsmann (2010), The influence of mechanical stiffness on caldera deformation and implications for the 1971-1984 Rabaul uplift (Papua New Guinea), Tectonophysics, 483, 399-412, doi:10.1016/j. tecto.2009.10.029.

Gottsmann, J., A. G. Camacho, J. Martí, L. Wooller, J. Fernández, A. García, and H. Rymer (2008), Shallow structure beneath the Central Volcanic Complex of Tenerife from new gravity data: Implications for its evolution and recent reactivation, Phys. Earth Planet. Inter., 168, 212-230.

Hammer, S. (1939), Terrain corrections for gravimeter stations, Geophysics, 4, 184-194.

Harford, C. L., M. S. Pringle, R. S. J. Sparks, and S. R. Young (2002), The volcanic evolution of Montserrat using ${ }^{40} \mathrm{Ar} /{ }^{39} \mathrm{Ar}$ geochronology, in The
Eruption of Soufrière Hills Volcano, Montserrat, From 1995 to 1999, Geol. Soc. Mem, vol. 21, edited by T. H. Druitt and B. P. Kokelaar, pp. 93-11, Geol. Soc., London, U. K.

Hautmann, S., J. Gottsmann, A. G. Camacho, N. Fournier, I. S. Sacks, and R. S. J. Sparks (2010a), Mass variations in response to magmatic stress changes at Soufrière Hills Volcano, Montserrat (W.I.): Insights from 4-D gravity data, Earth Planet. Sci. Lett., 290, 83-89.

Hautmann, S., J. Gottsmann, R. S. J. Sparks, G. S. Mattioli, I. S. Sacks, and M. H. Strutt (2010b), Effect of mechanical heterogeneity in arc crust on volcano deformation with application to Soufrière Hills Volcano, Montserrat, West Indies, J. Geophys. Res., 115, B09203, doi:10.1029/ 2009JB006909.

Hautmann, S., J. Gottsmann, A. Camacho, M. Van Camp, and N. Fournier (2013), Continuous and campaign-style gravimetric investigations on Montserrat 2006-2009, in The Eruption of Soufriere Hills Volcano, Montserrat, from 2000 to 2010, Geol. Soc. Mem., vol. 39, edited by G. Wadge, R. Robertson, and B. Voight, Geol. Soc., London, U. K., in press. Kenedi, C. L., R. S. J. Sparks, P. Malin, B. Voight, S. Dean, T. Minshull, M. Paulatto, C. Peirce, and E. Shalev (2010), Contrasts in morphology and deformation offshore Montserrat: New insights from the SEACALIPSO marine cruise data, Geophys. Res. Lett., 37, L00E25, doi:10.1029/2010GL043925.

Kloch, G., and J. Kryński (2008), Towards optimisation of the determination of terrain corrections with the use of the prism method, Environmental Engineering, Seventh International Conference, Vilnius, Lithuania, Selected Papers, 1345-1353.

Mattioli, G. S., R. A. Herd, M. H. Strutt, G. Ryan, C. Widiwijayanti, and B. Voight (2010), Long term surface deformation of Soufrière Hills Volcano, Montserrat from GPS geodesy: Inferences from simple elastic inverse models, Geophys. Res. Lett., 37, L00E13, doi:10.1029/ 2009GL042268.

Montserrat Volcano Observatory (2010), Weekly activity reports. [Available at http://www.mvo.ms.]

Moritz, H. (1980), Geodetic reference system 1980, J. Geod., 54(3), 395-405.

Nettleton, L. L. (1939), Determination of density for reduction of gravimeter observations, Geophysics, 4, 176-183.

Paulatto, M., et al. (2010), Upper crustal structure of an active volcano from refraction/reflection tomography, Montserrat, Lesser Antilles, Geophys. J. Int., 180, 685-696, doi:10.1111/j.1365-246X.2009.04445.x.

Reid, M. E., S. B. Christian, and D. L. Brien (2000), Gravitational stability of three-dimensional stratovolcano edifices, J. Geophys. Res., 105(B3), 6043-6056, doi:10.1029/1999JB900310.

Rowe, C. A., C. H. Thurber, and R. A. White (2004), Dome growth behavior at Soufrière Hills Volcano, Montserrat, revealed by relocation of volcanic event swarms, 1995-1996, J. Volcanol. Geotherm. Res., 134(3), 199-221, doi:10.1016/j.jvolgeores.2004.01.008.

Ryan, G. A., J. R. Peacock, E. Shalev, and J. Rugis (2013), Montserrat geothermal system: A 3D conceptual model, Geophys. Res. Lett., 40, 2038-2043, doi:10.1002/grl.50489.

Shalev, E., et al. (2010), Three-dimensional seismic velocity tomography of Montserrat from the SEA-CALIPSO offshore/onshore experiment, Geophys. Res. Lett., 37, L00E17, doi:10.1029/2010GL042498.

Shearer, P. M. (2009), Introduction to Seismology, Cambridge Univ. Press, Cambridge, pp. 410.

Sibson, R. H. (1994), Crustal stress, faulting and fluid flow, vol. 78, edited by J. Parnell, pp. 69-84, Geol. Soc. Spec. Publ., London, doi:10.1144/GSL. SP.1994.078.01.07.

Wadge, G. (2000), A DEM of the volcanic deposits of Soufriere Hills Volcano during 1999, Montserrat Volcano Observatory, Open File Rep., 00-07.

Walsh, J. B. (1975), An analysis of local changes in the gravity due to deformation, Pure Appl. Geophys., 113, 97-106.

Zimbelman, D. R., R. J. Watters, I. R. Firth, G. N. Breit, and G. Carrasco-Nuñez (2004), Strato-volcano stability assessment methods and results from Citlaltépetl, Mexico, Bull. Volcanol., 66(1), 66-79, doi:10.1007/s00445-003-0296-8.

Zurek, J., and G. Williams-Jones (2013), The shallow structure of Kīlauea caldera from high-resolution Bouguer gravity and total magnetic anomaly mapping: Insights into progressive magma reservoir growth, J. Geophys. Res. Solid Earth, 118, 3742-3752, doi:10.1002/ jgrb.50243. 